UDC 159.9.075

\title{
SYNTHESIS AS A PSYCHOLOGICAL METHOD: EVIDENCE OF USING THE SEMANTIC DIFFERENTIAL METHOD
}

\begin{abstract}
Rai T.I.
The purpose of the research is a psychological comprehension of the conceptual and formal aspects of methodology. This paper presents a theoretical analysis of the integral paradigm and synthesis as used in psychology. It dwells upon a formal methodology for integrating differentiated factors by the semantic differential method. The findings enable higher-level generalization and abstraction for describing systems as holistic phenomena to define their specificity, structure, and functional patterns. The semantic volume of the notion 'meaning'was identified as the one that reveals a common structure and order in the diversity of science-specific, unique and non-permanent meanings, each of which pertains to a specific stage of history and evolution. In this context, meaning can be efficiently represented as a holistic structure, a chard, a phenomenon that outlines systemic connections and hierarchy, allocates a specific volume to each semantic space, and defines the centers of gravity as the generalizing motive forces of the phenomena under consideration.

Keywords: conceptual methodology; formal methodology; integral paradigm; synthesis; symbol; meaning; semantic differential.

\section{СИНТЕЗ В МЕТОДОЛОГИИ \\ ПСИХОЛОГИИ НА ПРИМЕРЕ МЕТОДИКИ КЛАССА «СЕМАНТИЧЕСКИЙ ДИФФЕРЕНЦИАЛ»}

Рай T.И.

Статья посвящена психологическому осмыслению содержательной и формальной методологии. В статье приведень ре- 
зультаты теоретического исследования в области интегральной парадигмы и синтетического подхода в методологии психологии. Представлена формальная методология интеграции дифференцированных факторов на примере методики класса «Семантический дифференциал». Получены выводы, которые позволяют на более высоком уровне обобщения и абстракции описывать системы как целостные феномень, и таким образом определять их специфичность, структуру и закономерности функционирования. Было раскрыто семантическое пространство понятия «смысл》, которое обнаруживает общую структуру и порядок в многообразии индивидуальных для разных наук уникальныхх и изменчивых смыслов, обусловленных конкретным этапом историческо-эволючионного развития. Смысл представляется в виде иелостного символа схемы феномена, условно обозначая в нем системные связи, показывая иерархию, определяя объемы занимаемых семантических пространств, а также ичентры тяжести, как генерализующчие движущие силь рассматриваемых явлений.

Ключевые слова: содержательная методология; формальная методология; интегральная парадигма; синтез; символ; смысл; семантический дифференциал.

\section{Introduction}

By classical definition, scientific methodology is a doctrine of scientific methods and procedures. Methodology can be defined as a system of principles and methods for theoretical and practical efforts, or a doctrine defining that system. Differentiation and integration of scientific knowledge, as well as the critical points, or landmarks, of research paradigms affect the development of scientific methodology. These phenomena are at the core of the today's development of such methods and means that enable efficient coordination and methodological synthesis of different branches of science: a systemic approach, theoretical cybernetics, etc. The desire to integrate the disparate scientific knowledge, the fusion of analysis and synthesis in psychology are becoming essential to the integral paradigm that is gaining traction. 


\section{Literature review}

Such researchers as K.A. Abulkhanova-Slavskaya, A.V. Brushlinsky, V.V. Davydov, V.P. Zinchenko, V.A. Mazilov, Ye.D. Khomskaya believe psychology is in crisis today, which is partly due to its methodological core. V.V. Makedonskaya and V.V. Nikandrov note that where the methodology lacks rigor, empirical research becomes inefficient, as such lack of rigor hampers the clarity of original hypotheses, the soundness of discussion on experimentally found effects, any projection on any psychological phenomena; as a result, it becomes difficult to draw appropriate applied recommendations. Analysis dominates over synthesis; this and the resulting futility of experimental factual findings that lack theoretical ground are ever more noticeable. As a result, phenomenological descriptive research is gaining traction at the expense of substantial generalizations [12].

Substantial generalizations or meanings are also specific to the scientific paradigm used by the researcher. This can be easily traced by defining the concept of 'meaning'.

M. Csikszentmihalyi analyzes the semantics of 'meaning' and presents three interpretations [1]:

1. Meaning in the sense of end, purpose, and significance of something. The idea is that nothing happens at random; all events follow a singular pattern and have a purpose; they are ordered on a temporal scale and have causative links in-between. This sense of 'meaning' belongs to the classical paradigm.

2. Meaning as intention. Intentions manifest themselves in actions; people's goals are expressed in predictable, consistent, and orderly ways. This sense of 'meaning' pertains to the non-classical paradigm.

3. Meaning as a sign. In this sense, meaning helps order information, differential and structure the relations and correlation of phenomena and things, which results in a highly differentiated, complex knowledge, in a need for new principles behind a systemic approach. This essentially pertains to the post-non-classical paradigm.

From the standpoint of the integral paradigm and H. Heckhausen's 'fourth view' of human, which is that the behavior is determined by the 
person's ability to see the field of opportunity rather than the field of stimuli $[4,9]$, 'meaning' acquires a fourth interpretation:

4. Meaning as a symbol, a tool that orders the structure of holistic semantic spaces to reach beyond the information carried by singular flows, to interpret the holistic information flows in their integrated form, to understand the transients and relations between such flows, to control them and to order them on a temporal scale.

This last interpretation reveals a common structure and order in the diversity of science-specific, unique and non-permanent meanings, each of which pertains to a specific stage of history and evolution. In this context, meaning can be efficiently represented as a holistic structure, a chard, a phenomenon that outlines systemic connections and hierarchy, allocates a specific volume to each semantic space, and defines the centers of gravity as the generalizing motive forces of the phenomena under consideration.

\section{Problem statement}

The conceptual methodology covers the following problems: structure of scientific knowledge in general and of scientific theory in particular; laws of creation, functioning, and modification applicably to scientific theory; the conceptual framework of science and its individual branches; description of explanatory frameworks used in science; structure and procedural characteristics of scientific methods; conditions and criteria of scientific rigor.

Speaking of the formal aspects of this question, it should be noted that the formal methodology relates to analyzing the scientific meta-language, the structure of scientific explanation, the formal and formalized research methods: theorization and logical testing, as well as knowledge system typology. Consider for instance the Semantic Differential method (SD).

To today's interpretation of semantic space is based on rendering such space as a complex multicomponent system that comprises fractional subunits: semantic features, semantic multipliers, 'atoms of meaning' (L. Hjelmslev, B. Pottier, U. Weinreich, A. Martinet, S. Ullman, V.G. Gak, and Yu.D. Apresyan). 
Semantic Differential is a method designed to outline and analyze the cognitive and emotional components in a person's subjective view of individual semantic space pertaining to this or that phenomenon or object. The method builds upon categorical structures (factors) that are fundamental to their own differentiation and enhancement. A mathematical representation of semantic space is a effectively a transition from scalebased features to a less-dimensional base (categorial factors).

We believe that semantic differential can be used for synthesis. An outside perspective as opposed to differentiation and enhancement can provide more information about the holistic meanings and general trends in the analyzed phenomena to help identify the domain of their most necessary, useful, and sufficient development.

\section{Description of the research}

This approach attaches less importance to partial features of categorial aspects; rather, it prioritizes the choice of factors and their logical, energetic, and semantic relations.

Consider a 6-factor semantic space: activity (A), emotional evaluation $(\mathrm{E})$, potency $(\mathrm{P})$, order $(\mathrm{O})$, feel $(\mathrm{F})$, and comfort $(\mathrm{P})$. The first three factors were defined by $\mathrm{Ch}$. Osgood and interpreted as follows:

1. Activity: tension, activity, density, rapidity, and variability.

2. Evaluation: the degree of subjective satisfaction.

3. Potency: the intensity of motivational potential and the emotional state.

Order and Feel were used by L. Wassermann, Ye. Trifonova, K. Chyervinskaya to apply the SD method to the perception of time; they can be interpreted as follows:

4. Order: the degree of understandability, rhythmicity, reversibility, continuity, and indivisibility

5. Feel: the intensity, to which one reflects upon the reality 'here and now', upon intimacy, community, and openness.

The sixth structural unit is comfort, mentioned in particular by V.F. Petrenko [13]. This parameter shows how favorable the internal and external environment, including psychological factors, is for a person. It 
describes the tension of human's existential, social, mental, and physiological functioning. A descriptor of homeostasis, this structural unit is essentially an integral score of human life, their internal center of gravity and balance; as such, it is indicative of the stable and harmonious correlation of internal and external features.

Apparently, every scale is logic-, meaning-, and energy-connected to every other scale, which can be symbolized in the form of a five-pointed star, see Figure 1. The factors are rendered here as axes of a multidimensional space, where factorial connotations are represented as coordinates of points on the boundaries of semantic space.

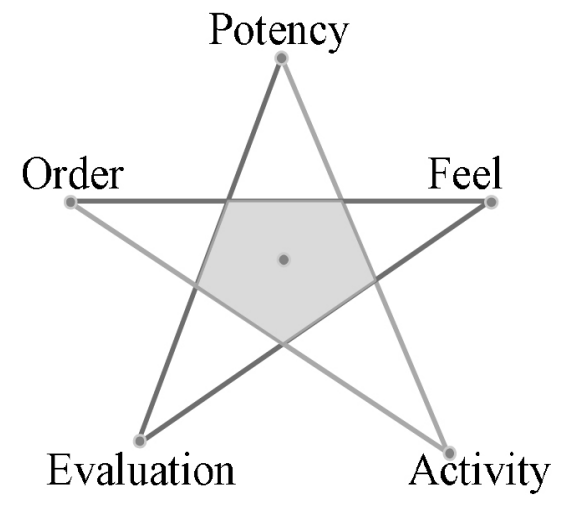

Figure 1. Six-factor semantic space

Apparently, the six-factor system splits into two subsystems: the red triangle of feel, evaluation, and potency; and the blue triangle of order, activity, and potency. Comfort characterizes the dynamics and homeostasis of the whole that comprises the two subsystems; as such, it is represented by the inner integrator.

Evaluation relates to feel, as any emotion has substance; and since the emotion is the motive force of the psyche, it also relates to potency. Activity correlates to order, as activity implies some procedure and some logic behind itself; this ultimately affects the required potency.

The inner pentagon stands for the cohesion of the entire semantic space; whether it is regularly or irregularly shaped depends on wheth- 
er the system is static or dynamic. The cohesion is indicative of the relations between parts of the whole (internal relations) and between the whole and its environment (external relations). This unity of the duality of relations - the comfort - is a fact we deem most valuable for psychologist's methodology. The relations represented as the two subsystems of the five-pointed star are complementary; their interaction is what drives the balance or dynamics, and thus the stability or volatility of the whole. If the comfort tends to zero or the external cohesion tends to infinity, the whole falls apart and becomes non-whole. If the internal cohesion tends to infinity, or the external one tends to zero, the object closes upon itself and loses its connection to the environment; expulsed from the environment, it dies. In any case, the existence of the whole is one of temporal discontinuity. The degree of cohesion, or comfort, alters all the properties of the whole and affects the very possibility of the existence of symbols and meanings. The development of the whole, whether progressive or regressive, is to a great extent shaped by the trends of its comfort, cohesion, and meaning.

The synthesis of SD factors shown herein enables identifying the perceivable and non-perceivable relations between structural factors, which are none other than the boundaries of inner space; they take form in the psychological continual space of the individual.

In the post-non-classical paradigm, semantic space was represented by the unique descriptive meta-language that decomposed its values into a fixed alphabet of categorial factors for semantic analysis that would find whether these values were similar or dissimilar by calculating the distance between the corresponding coordinates in the space. Such approach is associated with greater differentiation and significant complexity of processed data. In our approach, the entire semantic-space field is analyzed as a single unit that harmonizes the contradictions and merges them with a common meaning, a symbol; this helps integrate data and simplifies the procedure by considering a phenomenon as a whole for a clearer view of holistic properties and developmental trends. In this approach, a single metaphor, a symbol, a holistic image of the space represents the multiple levels, the text in text, the metaplanes that represent 
one aspect of knowledge through the lens of others, and thus the self-reflection of the system; as a result, the approach derives and outside perspective of the system for simpler holistic perception of the meaning.

\section{Conclusion}

Below are the findings of this review of the integrative approach in psychology with evidence of semantic differentials.

1. Universal semantic spaces that differentiate vocabulary from a variety of conceptual classes can be constructed by the same methods as partial semantic spaces for narrower conceptual classes.

2. By expanding the synthesis toolkit and using nonverbals, in particular visuals, one can reflect upon the trends and states of phenomena (e.g. of a personality) in general while outlining the phenomenal deficits, surpluses, and directions.

3. Synthesis generates a real system model; it leads to a greater generalization and abstraction in describing the system as a holistic phenomenon. Synthesis also outlines the completeness of the system's structure and composition, the patterns of its development and behavior.

4. Great importance is attached to the cohesion factors or binders (comfort in this case). These elements are valuable markers of the meaningfulness or meaninglessness of phenomena, thus of their utility, necessity, or possibility.

\section{References}

1. Csikszentmihalyi M. Flow: Psychology of Optimal Experience. Moscow: Alpina Non-Fiction, 2018. 460 p.

2. Csikszentmihalyi M. Some paradoxes in the definition of play. New York. Leisure Press, 1981. pp. 14-26.

3. Haas S. J., Fisk G. Confidence in word detection predicts word identification: implications for the unconscious perception paradigm. American journal of psychology, 2001. vol. 114. no.3. pp. 439-468.

4. Heckhausen H. Motivation and Action. St. Petersburg: Piter, 2003, 860 p.

5. Khun T.S. The essential tension: Selected studies in scientific tradition and change. University of Chicago Press, 1962. 366 p. 
6. Khun T.S. The structure of scientific revolution. Chicago: University of Chicago Press, 1962. 151 p.

7. Kintch W. Book review. Comprehension, a paradigm for cognition. American journal of psychology,1999. vol. 112. no. 3, pp. 489-195.

8. Kut'kina R.R. Diagnostika: teorija, praktika, instrumentari [Diagnostics: theory, practice, tools]. Vitebsk: Vitebskij gosudarstvennyj universitet im. P.M. Masherova, 2003, pp. 48-54.

9. Leontyev D.A. Questions of Psychology [Voprosy psikhologii], 2011, no. 1, pp. 3-27.

10. Leontyev D.A. Materialy mezhdunarodnoj konferencii [Proceedings of the international conference]. Moscow: Smysl, 2005, pp. 36-49.

11. Leontyev D.A. Psihologija smysla: priroda, stroenie i dinamika smyslovoj real'nosti [Psychology of meaning: nature, structure and dynamics of semantic reality]. Moscow: Smysl, 2007. 438 p.

12. Makedonskaya V. V., Nikandrov V. V. Vestnik of St. Petersburg University [Bulletin of St. Petersburg University]. St. Petersburg: St. Petersburg University, 2008, no.1, pp. 176-186.

13. Petrenko V.F. Psikhosemantika soznaniya [Psychosemantics of Consciousness]. Moscow: MSU Publ., 1988, 208 p.

14. Osgood Ch.E. Focus on Meaning: Explorations in Semantic Space. Mouton Publishers, 1979. $235 \mathrm{p}$.

15. Osgood Ch.E. Method and Theory in Experimental Psychology. Oxford, 1956. $800 \mathrm{p}$.

16. Vasserman L.I., Trifonova E.A., Chervinskaja K.R. Semanticheskij differencial vremeni. Jekspertnaja psihodiagnosticheskaja sistema $v$ medicinskoj psihologii [Semantic time differential. Expert psychodiagnostic system in medical psychology]. St. Petersburg: NIPNI im. V.M. Behtereva, 2009. 44 p.

\section{Сиисок литературы}

1. Вассерман Л.И., Трифонова Е.А., Червинская К.Р. Семантический дифференциал времени. Экспертная психодиагностическая система в медицинской психологии. СПб НИПНИ им. В.М. Бехтерева, 2009,44 c. 
2. Кутькина Р.Р. Семантический дифференциал как метод исследования индивидуального сознания личности // Диагностика: теория, практика, инструментарий. 2003. С. 48-54.

3. Леонтьев Д.А. Новые ориентиры понимания личности в психологии: от необходимого к возможному // Вопросы психологии. 2011. №1. C. 3-27.

4. Леонтьев Д.А. Проблема смысла в науках о человеке // Материалы международной конференции М. Смысл. 2005. С. 36-49.

5. Леонтьев Д.А. Психология смысла: природа, строение и динамика смысловой реальности. НПФ Смысл». 2007. 438 с.

6. Македонская В. В., Никандров В. В. Общенаучные принципы познания как методологические основы психологии // Вестник СанктПетербургского университета. 2008. № 1. С. 176-186.

7. Петренко В.Ф. Психосемантика сознания. М. Изд-во Моск. ун-та, 1988. $208 \mathrm{c}$

8. Хекхаузен Х. Мотивация и деятельность. СПб. Питер. 2003. 860 с.

9. Чиксентмихайи М. Поток: психология оптимального переживания. М. Альпина нон-фикшн. 2018. 460 с.

12. Csikszentmihalyi M. Some paradoxes in the definition of play // New York. Leisure Press. 1981. pp. 14-26.

13. Haas S.J., Fisk G. Confidence in word detection predicts word identification: implications for the unconscious perception paradigm // American journal of psychology. 2001. vol. 114. № 3, pp. 439-468.

14.Kintch W. Book review. Comprehension, a paradigm for cognition // American journal of psychology. 1999. vol. 112. № 3, pp. 489 195.

15. Khun T.S. The essential tension: Selected studies in scientific tradition and change. University of Chicago Press. 1962. 366 p.

16. Khun T.S. The structure of scientific revolution. Chicago: University of Chicago Press. 1962. $151 \mathrm{p}$.

10. Osgood Ch.E. Focus on Meaning: Explorations in Semantic Space. Mouton Publishers. 1979. 235 p.

11. Osgood Ch.E. Method and Theory in Experimental Psychology. Oxford. 1956. $800 \mathrm{p}$. 


\section{DATA ABOUT THE AUTHOR}

Ray Tatyana Ivanovna, Master's Degree Student

Chelyabinsk State University

129, Kashirin brothers St., Chelyabinsk, 454001, Russian Federation

tatyana.ray.82@mail.ru

\section{ДАННЫЕ ОБ АВТОРЕ}

Рай Татьяна Ивановна, студент магистратуры факультета психологии и педагогики

Челябинский Государственный Университет

ул. Братьев Кашириных, 129, г. Челябинск, 454001, Российская Федерачия

tatyana.ray.82@mail.ru 